\title{
THE MEMORY ARD HISTORIOGRAPHY OF THE FIRST WORLD WAR In ITALY
}

\section{La memoria y la historiografía de la Primera Guerra Mundial en Italia}

\author{
Paolo Ferrari \\ University of Udine \\ Dipartimento di Storia e Tutela dei Beni Culturali
}

paolo.ferrari@uniud.it

The memory and historiography of the First World War in Italy may be divided into three broad periods. During the immediate post-war period (1918-1922) debate mainly focused on such issues as the Italian defeat at Caporetto in 1917, the scandal of war expenses, and the human costs of the conflict. In the subsequent decades (1922-1960), fascism was presented as the heir of the war, which became a fundamental element of its nationalist identity as well as part of the rituals of the regime. In the new post-1945 democratic Italy the nationalist interpretation of the war survived in a number of respects. Perspectives on the war were, however, revised over the next decades (1960-2014). The new cultural tendencies of the 1960s produced a broader and more critical approach to the conflict which now encompassed the study of ordinary soldiers, the strain of the fighting and dissent from the war. In more recent times these trends have continued, and new studies have emerged which further our understanding of the Italian experience of the conflict, but many aspects of the war, including the international context (such as Italy's enemies), are still relatively neglected. Moreover, although there is a keen public interest in the First World War in north-east Italy, which was the theatre of operations, the period 19151918 is probably part of a faraway past for most Italians.

Italy, First world war, memory, military history, national identity Italia, Primera Guerra mundial, memoria, historia militar, identidad nacional

Q Key words 
La memoria e historiografía de la Primera Guerra Mundial en Italia se puede dividir en tres amplios periodos. A lo largo del periodo inmediato a la postguerra (1918-1922) el debate se centró principalmente en temas como la derrota italiana en Caporetto en 1917, el escándalo de los gastos en la guerra y el costo humano del conflicto. En las décadas subsiguientes (1922-1960) el fascismo se presentó como el heredero de la guerra, convirtiéndose en un elemento fundamental de su identidad nacional así como de los ritos del régimen. En la nueva Italia democrática tras 1945 la interpretación nacionalista de la guerra sobrevivió en muchos aspectos. En cambio, las perspectivas sobre la guerra se revisaron a lo largo de las décadas siguientes (1960-2014). Las nuevas tendencias culturales de los años 60 produjeron un acercamiento más amplio y más crítico al conflicto, que ahora abarca el estudio de los soldados corrientes, la presión de la lucha y la disconformidad con la guerra. En tiempos más recientes estas tendencias han continuado, y han emergido nuevos estudios que amplían nuestro entendimiento de la experiencia italiana del conflicto, pero muchos aspectos de la guerra, incluyendo el contexto internacional (como por ejemplo los enemigos de Italia) aún están relativamente desatendidos. Aún es más, aunque hay un interés genuino en la Primera Guerra Mundial en el noreste de Italia, que fue escenario central de las operaciones, el periodo 1915-1918 probablemente forma parte de un pasado muy lejano para la mayoría de los italianos.

\section{8-1922}

For Italy, victory in the First World War paradoxically resulted in the collapse of the liberal state and brought Benito Mussolini to power in 1922. In the aftermath of the conflict the country went through an intense period of economic and social strife. During this crisis the war came to play an important role in public discourse and the political struggle. It had infused politics with violence whilst fomenting the idea that opponents had to be treated as "enemies" and wartime sacrifices had to be repaid. Indeed, the fascist movement drew on the experience of the war in order to mobilise its supporters and allies in a struggle against the "anti-national forces". Disillusioned veterans, as well as ordinary civilians who had suffered the consequences of the conflict on the home front, were drawn to the movement while economic élites looked back at the war experience as a period of authoritarian social control and increasingly lost faith in the usefulness of the liberal state for their own interests. The alleged failure of Italy to secure its aims at the peace conference in Versailles was presented by nationalists and fascists as evidence of a further failure of the liberal establishment. It was accused of being unable to obtain the fruits of victory and secure the promises given to Italy by the allies under the Pact of London in 1915 which had brought the country into the war.

Initially, post-war public debate focused on two themes: the major defeat of the Italian army by the forces of Germany and Austria-Hungary at the Battle of Caporetto in October-November 1917, and the scandal of war expenses. The report of the official inquiry into Caporetto, which was published in 1919, defended elements of the military and political leadership (General Pietro Badoglio, corps commander in a sector overrun by the enemy, General Gaetano Giardino, minister of war, and Prime Minister Vittorio Emanuele Orlando); was highly critical of the commanderin-chief, General Luigi Cadorna; and presented the defeat as a result of the superiority of the enemy, and not, as Cadorna claimed, as a consequence of internal sabotage by the domestic 
opponents of the war. This was an important conclusion because the main political forces - the socialists, catholics and the liberals loyal to Giovanni Giolitti (who had opposed Italy's entry into the war) - had often been accused of subverting the war effort and thus had been strictly controlled by the police and military forces. Now they assumed a new and central role in the unfolding drama of Italian politics. The debate over war expenses also became clearly politicised. In 1920 a parliamentary inquiry was launched to investigate the financial scandals and high profits of war industries while soldiers (who endured the terrible conditions of the trenches) and most of the civilian population (who suffered from shortages of foodstuffs) had struggled through the conflict. But one of the first decisions of Mussolini when he became prime minister - a decision designed to placate the economic élite that had supported his movement and his nomination as prime minister - was to close down the inquiry. Thus some private companies and great industrial concerns were not tainted by the evidence of wartime wrongdoings.

In historiographical terms, during this period most of the published works relating to the war were the memoirs of, and other accounts by, generals and politicians who wished to justify their actions during the conflict. For example, books appeared by the two main players responsible for the defeat at Caporetto: Luigi Cadorna and Luigi Capello (the commander of the Second Army). ${ }^{1}$ Yet ordinary folk also wrote about their war experiences. The recollections of veterans such as Piero Jahier (1919) and, a few years later, Carlo Salsa (1924) became well known, but other lesser-celebrated narratives appeared. These works were in part reflections on the war but also expressions of the great post-war mourning, written in memory of those who had lost their lives.

Soon after the end of the conflict the bodies of the soldiers, buried in the cemeteries close to the battlefront, began to be collected in charnel houses. The desire of the veterans, who wished to play an important role in shaping the memory of the conflict, to commemorate their fallen comrades matched the wishes of the post-war liberal governments, and later the fascist regime, to use the process of collective mourning for political purposes: to shape a new sacred image of a united nation after the great struggle. This was a key message in a period characterised by an intense and violent political struggle between the liberal state and its enemies. The memory of the dead soldiers thus became the expression of a civil religion which different political forces wanted to use for their own purposes.

The liberal government did not organise any great commemoration on the first anniversary of the end of the war in 1919. The following year the anniversary was celebrated with a ceremony which put the king at the centre of the scene, yet in 1921, with the government facing an increasing lack of support and legitimacy, the liberal élite tried to use the commemoration to defend its right to rule the nation. In contrast, in Rome and many towns across the country, the nationalist and fascist forces sought to define themselves as the main defenders of the memory of the war. Groups who had opposed the war and did not take part in the ceremonies, such as the socialists, were depicted as the "internal enemy" and Mussolini portrayed himself as representing the patriotic middle and upper classes and the one true defender of the sacred memory of the conflict. ${ }^{2}$

In the context of this confrontation over the memory of the war, the most important expression of national collective grief was the burial of the Milite ignoto (the unknown soldier) at the

1 See Cadorna (1921); Capello (1920a, 1920b). It is not possible to cite, in a short article, all the key studies on the First World War published in Italy. The reader may consult the bibliographies published at the end of the best synthesis on the war (for military, political and cultural aspects, in particular): Isnenghi \& Rochat (2014).
For Italy, victory in the First World War paradoxically resulted in the collapse of the liberal state and brought Benito Mussolini to pouer in 1922 
base of the Vittoriano, in the centre of Rome, on 4 November 1921. ${ }^{3}$ A special commission had collected the bodies of eleven unknown soldiers from eleven Italian theatres of the war, and the mother of a deceased soldier - a woman from Trieste whose son's body was never recovered - chose one of them as a representative of all the war dead. The body was transferred from Aquileia to Rome by train in an open carriage and at each station local people paid their respects. The soldier was buried at the foot of the monument dedicated to Vittorio Emanuele II, the Altare della Patria (altar of the homeland), which became a tomb to the unknown warrior and the central monument to the fallen in the capital.

While the Altare della Patria was a memorial to all the Italian dead, many local monuments were constructed from 1918. These early monuments, which were the product of local initiatives, usually included a list of the war dead of a town or village and indicated the impact the war had had on each community. In addition to this, in October 1922 one of the last decrees of the liberal government was to create four "monument zones". These zones - located in the Pasubio, Grappa, Sabotino and San Michele mountains - were intended to commemorate the different Italian theatres of war and were to be preserved in their historical integrity. These "sacred" areas became the sites for reunions of veterans, such as the Alpini (mountain troops), or places of pilgrimage for tourists and walkers. But, once in power, the fascists wanted to be the sole custodians of the memory of the war.

\section{2-1960}

Fascism presented itself as the heir to the war. This became a fundamental element of its identity and helped to shape the rituals of movement, provided legitimation for its members and provided the justification for the persecution of "anti-national" forces. Historiographically, as well as in wider public discourse, the war remained an untouchable myth. In 1925 the great publishing house, Mondadori, launched a Collezione italiana di diari, memorie, studi e documenti per servire alla storia della guerra del mondo under the direction of Angelo Gatti, the historian to the supreme command. In 1927 the historical office of the Italian army started to produce a multi-volume official survey of the war, L'esercito italiano nella grande guerra, 1915-1918, which became a reference text for military historians of the conflict. But during the fascist regime it was impossible, for example, to discuss the defeat at Caporetto. As a result, it was only in 1967 that the historical office's volumes on the events of October-December 1917 appeared. Indeed, before 1945 few independent-minded studies were produced. Notable exceptions were Piero Pieri's La nostra Guerra tra le Tofane (1927/1996) and Roberto Bencivenga's Saggio critico sulla nostra guerra (1930-1938). Instead of peddling the fascist simplifications of the conflict, these works were more nuanced and critical of the Italian war effort. Yet in contrast to these studies, those by Gioacchino Volpe (a medievalist who emerged as the official historian of the fascist regime) promoted the fascist view of the war. ${ }^{4}$ According to his interpretation, out of the challenges of the conflict Italy emerged as a new, united nation, conscious of its identity and destiny.

\section{Fascism presented itself as the heir to the war.} This became a fundamental element of its identity

3 The date of 4 November marked the armistice between Italy and Austria-Hungry in 1918 and became the anniversary of victory which, uniquely, survived under liberal, fascist, and republican Italy. It is also worth mentioning that, in all commemorative ceremonies, the dead soldiers are called caduti, that is "fallen", an euphemism associated with their role as victims of the war.

4 See, for example, the following works by Volpe: 1930a; 1930b (a book for Italian schools abroad); and 1940. 
The fascist regime put its stamp on the symbolic spaces related to the memory of the war, leaving no room for autonomous initiatives. In December 1922 the under-secretary at the Ministry of Education in Mussolini's government decided that each town would create a memorial park or avenue, where the names of the fallen soldiers were to be remembered alongside the fascist dead during the civil clashes of the immediate post-war years. This was intended to indicate a direct connection between the war and the fascist movement and students were to plant trees to represent the war dead as a way of linking the different generations together. The fascist effort to create a civil religion, based on symbols and rituals related to the memory of the war, also included the creation of museums and the naming of streets and squares which, again, linked together the dead soldiers with the "martyrs" of fascism.

A great fascist propaganda effort was directed at Italian schools, which became one of the most important vehicles for the transmission of fascist political and military ideas. The school curricula, along with the erection of memorial stones on school premises, reminded the pupils of the sacrifices of fallen, the great collective war effort, and the victory, as the basis of the new fascist era and encouraged them to participate in the future successes of the Italian army. Meanwhile, across the nation, 24 May (the date of the start of the war in 1915) and 4 November (the anniversary of victory) became, together with the fascist anniversaries, the most important days in the popular celebration of the fascist nation. The fact that 4 November, a date close to the anniversary of Mussolini's "March on Rome" on 28 October, was in part absorbed by the latter meant the memory of the war became even more closely connected with fascist rituals. In the late 1920s, and into the 1930s, this conflation undermined the commemoration of the war.

By the 1930s about forty military cemeteries, charnel houses and war memorials had been built in Italy - most of them after 1922. The most important memorial was the Sacrario Militare in Redipuglia, where 100,187 soldiers (60,330 of them unknown) are buried. Constructed on the site of a previous cemetery inaugurated in 1923, it was completed between 1936 and 1938 and represents both the appropriation of the memory of the war by fascism and the desire to create grand architectural structures where the identity of the individual is subsumed by the authority of the state. Furthermore, as has been observed, the location of the memorial, close to Trieste (which was acquired by Italy from Austria-Hungary at the end of the war), made it appear both as a sentinel of the new Italian border and an expression of the power of the Italian nation. ${ }^{5}$ After 1945 the fascist symbols were removed and the Sacrario Militare in Redipuglia continues to be the principal Italian war memorial and focus of First World War commemorations.

In the new post-1945 democratic Italy the nationalist interpretation of the war survived in a number of respects. It was often portrayed as the final conflict of the Risorgimento, fought in order to obtain Trento and Trieste. The wartime record of the armed forces was also viewed retrospectively in a more positive light since Mussolini's forces had, colonial enterprises apart, been badly defeated on all fronts in the Second World War, resulting in German occupation and a partisan war (which was in fact also a civil war). If we add that democratic Italy was reluctant to engage publicly in a critical appraisal of the fascist experience, including its foreign wars, we can begin to understand how the 1915-1918 conflict - the greatest Italian victory (against great powers) since the foundation of the nation in 1861 - remained a fundamental reference point for the cultural and political forces of the right.
The fascist effort to create a civil religion, based on symbols and rituals related to the memory of the war, also included the creation of museums and the naming of streets and squares 
Yet, together with the Risorgimento, the First World War was, for the centrist and left-wing political traditions which came together in the wartime Italian resistance movement and in the foundation of the Republic, an event that could, in the difficult reconstruction of a new post-war public memory and national identity, rekindle a sense of patriotism which the disasters of fascism had destroyed in most Italians. After Mussolini's dictatorship, and the partisan/civil war of 1943-1945, the experience of 1915-1918 was considered as a means to rediscover the collective history which had brought Italy to democracy. At the same time, the 4 November anniversary (which had been celebrated in the liberated parts of the country after 1944 and was to replace 24 May as the key commemorative day) was used to create a new legitimacy for the armed forces - which had supported the fascist movement and had become the instrument of its wars - and to affirm the continuity of the state. In 1947, the anniversary was transformed from the "Celebration of the Victory" to the "Day of the National Unity" and the focus of the commemoration (chiefly interpreted as the day of the armed forces) became pity for the dead soldiers and the condemnation of war as a means to settle international disputes, which the 1948 constitution affirmed in article eleven. In collectively mourning the dead, the post-war Christian Democratic governments could - in a country still divided by internal political struggles now exacerbated by the Cold War - create a moment of unity.

The politics of the Cold War quickly led to former members of the partisan forces being excluded from public commemorations of the war. In response, the left opposition, who defended the values of the wartime Resistance, became reluctant to participate in rituals of collective remembrance which, by often commemorating fallen soldiers from the Second World War alongside their First World War comrades, included those who had been responsible for war crimes and who had fought against the resistance movement, thus either assuaging or exonerating the fascists. The 4 November anniversary became part of that symbolic conflict and, in turn, became connected to the international problems facing Italy and the struggle with Moscow and Belgrade over its eastern border. It was only towards the end of the 1950s and into the 1960s that the anniversary became less contentious. At the same time, the opening up of barracks and other military establishments to the public indicated the forging of a new relationship between the armed forces and the population.

In the meantime, in school textbooks the war was largely presented as the "fourth" Risorgimento war, fought for freedom against the old Austrian enemy and for possession of the cities of Trento and Trieste. This interpretation preserved the "necessity" of such a great tragedy, presenting it as a turning point in Italian history. Indeed, for many decades of the Republic, the victory in 1918 was the last subject studied in secondary school history courses. Only in the second half of the 1990s did the rest of the twentieth century make it into the curriculum.

\section{0-2014}

A new and wider interpretation of the war began in the early 1960s. If we need to identify a watershed moment, we can cite the appearance of an influential film and a path-breaking book. La Grande Guerra (1959), an internationally-acclaimed film directed by Mario Monicelli, for the first time presented the war from the point of view of ordinary soldiers, in the context of an unintelligible tragedy and with a clear attention to class conditions. ${ }^{6}$ The following year a fresh interest in the popular experience of the conflict was implicit in Paolo Spriano's study of
For many decades

of the Republic,

the victory in

1918 mas the last

subject studied in

secondary school

history courses.

Only in the second

half of the 1990s

did the rest of the

twentieth century

make it into the

curriculum

6 In relation to this, we need to acknowledge the influence of Stanley Kubrick's innovative Paths of Glory (1957). 
the workers of Turin: Torino operaia nella Grande Guerra (1960). Turin was one of the main centres of war production and, in August 1917, the scene of a popular revolt due to a shortage of foodstuffs and poor living conditions.

In the second half of the decade, this historiographical trend continued. With books by Mario Isnenghi, I vinti di Caporetto (1967), and Enzo Forcella and Alberto Monticone, Plotone d'esecuzione (1968), attention now focused on the defeat at Caporetto and the victims of a repressive military system. These works were reinforced by another important film, Uomini contro (1970), directed by Francesco Rosi, which portrayed the hardships of trench warfare and the mutinous behaviour of the troops. It was based on Emilio Lussu's novel Un anno sull'Altipiano (1938). These treatments, focusing largely as they did on the frontline conditions, the stresses and strains of fighting, and dissent from the conflict, transformed the study of 1915-1918. Other influential studies also signified changing approaches. Giorgio Rochat's L'esercito italiano da Vittorio Veneto a Mussolini (1919-1925) (1967) connected the war to the rise of fascism and investigated the relationship between the military world and the Italian political élite. Isnenghi's Il mito della Grande Guerra (1970) explored the role of the Italian intellectuals in the creation of a "myth" of the war.

Much of this chimed with the changing social values of the 1960s. This period came to be characterised by criticism of various forms of authority and challenges to prevailing myths - a process in turn expedited by the new approaches to the study of the war. These new perspectives also witnessed a growing anti-militarism among young Italians. As a result, commemorative events often seemed out of tune with significant elements of the population. It many respects, they came to be seen as more a part of a nationalistic and fascist tradition rather than a republican identity.

In recent decades important new publications have appeared. Among them, Antonio Gibelli's L'officina della Guerra. La Grande Guerra e le trasformazioni del mondo mentale (1991) and Giuliana Procacci's Soldati e prigionieri italiani nella Grande Guerra. Con una raccolta di lettere inedite (1993), make extensive use of the letters written by and to soldiers (subject to censorship), which give us fresh perspectives on the conditions and mentalités of the soldiers, with particular attention paid to the refusal to fight, whether from indiscipline or mental breakdown. New political insights have also been offered. Angelo Ventrone's La seduzione totalitarian. Guerra, modernità, violenza politica (1914-1918) (2003), for example, explored the role of the war in creating the conditions for Italian totalitarianism, while Lucio Ceva's Teatri di Guerra. Comandi, soldati e scrittori nei conflitti europei (2005) investigated the links between Italian military institutions, the constitutional monarchy and Italian, as well as other European, writers of the First World War.

Yet this period has also witnessed relatively little interest in the work of scholars of other belligerent nations. Some published works have had an influence, such as Paul Fussell's, The Great War and the Modern Memory (Italian edition, 1984); Eric Leed's No Man's Land. Combat E Identity in World War I (Italian edition, 1985) and George Mosse's, Fallen Soldiers. Reshaping the Memory of the World Wars (Italian edition, 1990). But there has not been a large interaction with other historiographies and the volumes published to mark the centenary of the outbreak of the war confirm this general trend. ${ }^{7}$ As an example of the lacunae, the new tactics introduced
There has not been a large interaction with other historiographies and the volumes published to mark the centenary of the outbreak of the war confim this general trend 
by the German army, which in turn influenced the Austria-Hungarian armies in 1917-1918, have been extensively analysed abroad but, as Lucio Ceva reminds us, have been almost overlooked in Italy, even if they played an important role in the defeat at Caporetto. ${ }^{8}$

In addition, studies of the economic history of the Italian home front have not played a prominent role in the historiography until comparatively recently. Twenty years after Spriano's book, Alessandro Camarda and Santo Peli published an innovative study of "the other army" - the industrial workers: L'altro esercito. La classe operaia durante la prima guerra mondiale (1980). But this remained an isolated example of such a work until scholars such as Luigi Tomassini produced Lavoro e guerra. La mobilitazione industriale italiana (1997) and Barbara Curli investigated women workers in Italiane al lavoro 1914-1920 (1998). Likewise, the general history of wartime industrial activity has not received much attention until the last few years. This is surprising since Italian industry was shaped by war. Industrial development from the 1880s was closely connected to military needs and the Italian industrial take-off, from the last years of the nineteenth century until 1914, was followed by war mobilisation. Many industrial concerns profited enormously during the conflict and the most successful, such as Fiat, were able to exploit both market and state demand. The period 1915-1918 also redistributed power inside the industrial system, leading to the creation of a new economic élite, and to a deep transformation of a country which was, by 1900, still mainly an agricultural one. Furthermore, the war, as we have seen, was a period of great financial scandals, due to many reasons: the great military demand for war materials; the political decision to condone large profits; and the inability of the state to control industry. However, building on studies of particular industries by Valerio Castronovo (1971) and Franco Bonelli (1975), these themes have begun to be investigated by academics such as Luciano Segreto in Marte e Mercurio. Industria bellica s sviluppo economico in Italia 1861-1940 (1997), and Andrea Curami as outlined in Italia Contemporanea (2010). Curami's research, in particular, promoted a new vision of the relationships between industry and the Italian state. ${ }^{9}$

Despite these historiographical advances, there is much work to be done. We still, for example, do not have a general social history of Italy during the period. Nor has there been much detailed research, for instance, on Udine, which was "the capital" of the war and a centre of mobilisation close to the front, or on the region of Friuli. This was the main Italian theatre of the war, home to millions of soldiers, and suffered under Austrian and German occupation. ${ }^{10}$

Today the memory of the war is most alive in the north-east of Italy, where the conflict was fought. This is demonstrated by the many war-related guide books, and other works on particular battles and other aspects of the conflict, for tourists and others who come to walk the battlefields and enjoy the mountainous terrain. Alongside these, many small museums in the region feature documents and artefacts from the period with connections to local traditions and identities. To mark the centennial commemoration of the outbreak of the conflict, central government, regional administrations, and school authorities, have initiated various war-related education projects to remember the role of Italians in the war, and the Italian television chan-

8 See Ceva (2012). In general, most Italian studies retain a national perspective. There are, however, some exceptions such as Massignani (1995) and Rastelli \& Massignani (Eds) (2002).

9 Ferrari, P. (Ed.) (2010, December). The participation of Italy in the armament race before the war has not attracted many scholars, but we can cite pioneer studies by Webster (1974) and Ferrari (2004).

10 But there are several works on the Austrian and German occupation of the region in 1917-1918 which focus on the conditions of the civil population, including those who left the war zone (altogether some 600,000 refugees fled from Friuli and the other major theatre, Altipiano di Asiago).

\section{Despite these} historiographical advances, there is much work to be done. We still, for example, do not have a general social history of Italy during the period 
nel, Rai-storia, has commissioned a series of documentaries about the period intertwining the views of scholars with arresting visual images. In 2014 the main commemorative events were a concert at Redipuglia on 6 July at which Riccardo Muti conducted a 400-strong orchestra and chorus, drawn from the major belligerent nations, in a performance of Verdi's "Requiem". In attendance were the presidents of Italy, Austria, Slovenia and Croatia. This was followed on 13 September by a visit from Pope Francesco to Redipuglia. After a private visit to the nearby Austro-Hungarian cemetery, the Pope, whose grandfather had fought with the Italian army on the nearby battlefields during the Isonzo campaign, celebrated mass at the Italian shrine and in his homily affirmed, pedagogically, that "War is madness."

In Italy, the First World War is often now considered a great and meaningless tragedy at the heart of which rests the commemoration of the fallen soldiers. The war thus serves as a warning for a society which seems to reject armed conflict - even its military missions abroad are called "peace missions" - and which also continues to display a reluctance fully to explore the experience of the war in Italian culture and history. Meanwhile, the memory of the dead is still important to the idea of a national community. This includes the role of the conflict in the creation of the Republic, even if it is not always easy for those on the left - who see the war as part of a chain of historical events which led from the Risorgimento, to the Resistance and to the Republic - to reconcile internationalism, class identity, and patriotism. But whether any of this will encourage the majority of Italians to take more of an interest in the conflict is still left to be seen. Most likely, the events of 1915-1918 will remain part of a faraway past for most of the population, who are more worried about the political, economic and social problems that continue to beset the country.

\section{Reference list}

Bencivenga, R. (1930-1938). Saggio critico sulla nostra Guerra, vol. 5. Rome: various publishers.

Bonelli, F. (1975). Lo sviluppo di una grande impresa in Italia. La Terni dal 1884 al 1962. Torino: Einaudi.

Cadorna, L. (1921). La guerra alla fronte italiana fino all'arresto sulla linea del Piave e del Grappa. Milano: Fratelli Treves.

Camarda A. \& Peli, S. (1980). L'altro esercito. La classe operaia durante la prima guerra mondiale. Milano: Feltrinelli.

Capello, L. (1920a). Note di guerra. Milano: Treves.

Capello, L. (1920b). Per la verità. Milano: Treves.

Castronovo, V. (1971). Giovanni Agnelli. Torino: Utet.

Ceva, L. (2005). Teatri di guerra. Comandi, soldati e scrittori nei conflitti europei. Milano: Angeli.

Ceva, L. (2012). Postfazione. In N. Papafava, Da Caporetto a Vittorio Veneto. Roma: Edizioni di Storia e letteratura, Roma.

Curli, B. (1998). Italiane al lavoro 1914-1920. Venezia: Marsilio.

Dogliani, P. (1997). Redipuglia. In M. Isnenghi (Ed.), I luoghi della memoria. Strutture ed eventi dell'Italia unita. Roma-Bari: Laterza. 
Ferrari, P. (Ed.). (2010, December). L'industria bellica nella storia d'Italia. Economia e tecnologia negli studi di Andrea Curami. Italia contemporanea, n. 261.

Ferrari, P. \& Massignani, A. (2014). 1914-1918. La guerra moderna. Milano: FrancoAngeli.

Ferrari, P. (2004). Verso la guerra. L'Italia nella corsa agli armamenti 1884-1918. Valdagno: Rossato.

Gibelli, A. (1991). L'officina della guerra. La Grande Guerra e le trasformazioni del mondo mentale. Torino: Bollati Boringhieri.

Gibelli, A. (2014). La guerra grande. Roma-Bari: Laterza.

Isnenghi M. \& Rochat, G. (2014). La grande guerra 1914-1918 (first ed. 2000). Bologna: Il Mulino.

Isnenghi, M. (1970). Il mito della grande Guerra. Bari: Laterza.

Isnenghi, M. (1997). La grande guerra. In M. Ishnenghi (Ed.), I luoghi della memoria. Srutture ed eventi dell'Italia unita. Rome-Bari: Laterza.

Jahier, P. (1919). Con me e con gli alpini. Firenze: La Voce.

Labanca N. (Ed.). (2014). Dizionario storico della prima guerra mondiale. Roma-Bari: Laterza.

Lussu, E. (1938). Un anno sull'Altipiano. Paris: Edizioni italiane di cultura.

Massignani, A. (1995). Le truppe d'assalto austro-ungariche nella Grande guerra. Valdagno: Rossato.

Mondini, M. (2014). La guerra italiana. Partire, raccontare, tornare 1914-18. Bologna: Il Mulino.

Pieri, P. (1996). La nostra Guerra tra le Tofane (first ed. 1927). Trieste: Lint.

Procacci, G. (1993). Soldati e prigionieri italiani nella Grande guerra. Con una raccolta di lettere inedite. Roma: Editori riuniti.

Rastelli A. \& Massignani, A. (Eds.). (2002). La guerra navale, 1914-1918. Un contributo internazionale alla guerra in Mediterraneo. Valdagno: Rossato.

Ridolfi, M. (2003). Le feste nazionali. Bologna: Il Mulino.

Rochat, G. (1967). L'esercito italiano da Vittorio Veneto a Mussolini (1919-1925). Bari: Laterza.

Salsa, C. (1924). Trincee. Milano: Sonzogno.

Segreto, L. (1997). Marte e Mercurio. Industria bellica s sviluppo economico in Italia. Milano: FrancoAngeli.

Tomassini, L. (1997). Lavoro e guerra. La mobilitazione industriale italiana. Napoli: Edizioni scientifiche italiane.

Ventrone, A. (2003). La seduzione totalitaria. Guerra, modernità, violenza politica (1914-1918). Roma: Donzelli.

Volpe, G. (1930a). Ottobre 1917. Dall'Isonzo al Piave. Milano-Roma: Libreria d'Italia.

Volpe, G. (1930b). I fatti degli Italiani e dell'Italia, "letture storiche". Milano: Mondadori.

Volpe, G. (1940). Il popolo italiano tra la pace e la guerra (1914-1915). Milano: Ispi.

Webster, R. A. (1974). L'imperalismo industriale italiano. Studio sul preFascismo 1908-1915. Torino: Einaudi. 